\title{
Ultrastructural evidence of autoinfection in the gills of Atlantic cod Gadus morhua infected with Loma sp. (phylum Microsporidia)
}

\author{
Luis E. Rodriguez-Tovar ${ }^{1}$, Dorota W. Wadowska ${ }^{2}$, Glenda M. Wright ${ }^{3}$, \\ David B. Groman ${ }^{4, *}$, David J. Speare ${ }^{4}$, Darryl S. Whelan ${ }^{5}$ \\ ${ }^{1}$ Department of Pathology, College of Veterinary Medicine, Autonomous University of Nuevo Leon, CP 64930 Monterrey, Mexico \\ ${ }^{2}$ Electron Microscopy, ${ }^{3}$ Department of Biomedical Sciences, and ${ }^{4}$ Aquatic Diagnostic Services, Atlantic Veterinary College, \\ University of Prince Edward Island, Charlottetown, Prince Edward Island C1A 4P3, Canada \\ ${ }^{5}$ Newfoundland Department of Fisheries and Aquaculture, St. John's, Newfoundland A1B 4J6, Canada
}

\begin{abstract}
Infection by a microsporidian of the genus Loma was found in gills of cod Gadus morhua. Xenomas contained parasites in multiple stages of development. Some spores looked empty and had everted polar tubes, which were either straight or coiled. These polar tubes were scattered throughout the xenoma cytoplasm, and some of them pierced the plasma membrane. Those outside of the xenoma penetrated neighboring cells, including blood cells. These observations suggest that a mechanism of autoinfection could occur in blood cells and gill tissue, perpetuating the disease in the host.
\end{abstract}

KEY WORDS: Ultrastructure · Microsporidia · Xenoma · Everted polar tube · Autoinfection · Loma sp. · Cod

\section{INTRODUCTION}

Microsporidians belonging to the genus Loma are intracellular spore-forming parasites characterized by the formation of xenomas. The life cycle for Loma sp. is little understood, but it is accepted that it begins after host-ingestion of infective spores (Speare et al. 1998, Shaw \& Kent 1999). Spores evert their polar tubes in the gastrointestinal tract due to sudden $\mathrm{pH}$ changes in the digestive milieu (Cali \& Takvorian 1999). These everted polar tubes then penetrate susceptible host cells, such as enterocytes or intraepithelial leucocytes (Sánchez et al. 2001, Rodríguez-Tovar et al. 2002), and infective sporoplasms are injected. The dissemination of the parasite from the gut to the gills probably occurs via leucocytes (Desportes-Livage 2000, Lom \& Nilsen 2003). Infected leucocytes, containing immature forms of the parasite (meronts), can be ingested by the pillar cells, permitting intracellular parasite development and eventual xenoma formation in the gills (Rodriguez-
Tovar et al. 2002). The rupture mechanism of xenoma and infection of new fish was described by Speare et al. (1998). Apparently healthy fish, however, have been reported to contain intact xenomas in gills (Ramsey et al. 2001), which suggests prolongation of the disease by an autoinfective mechanism. Autoinfection has been proposed to occur in several microsporidians (Cali \& Takvorian 1999), including Loma sp. (Shaw et al. 1998). Everted polar tubes originating from xenomas and confined within originating xenoma have recently been reported for $L$. salmonae in rainbow trout Oncorhynchus mykiss (Rodriguez-Tovar et al. 2003). Both intra- and extraxenomal everted polar tubes have been reported for L. myrophis in the Amazonian fish Myrophis platyrhynchus (Matos et al. 2003). The objective of the present report is to describe the ultrastructural features of xenoma formed by Loma sp. in the gills of Atlantic cod, with emphasis on the eversion event and the significance of cells implicated in the dissemination of the disease. 


\section{MATERIALS AND METHODS}

Aquaculture reared, yearling Atlantic cod Gadus morhua originating from a recirculating facility in Newfoundland were necropsied as part of a routine health check. Gill samples were collected and stored in a modified Karnovsky's fixative (4\% paraformaldehyde, $1 \%$ glutaraldehyde) then sent to the Electron Microscopy Laboratory at the Atlantic Veterinary College, University of Prince Edward Island, for diagnostic investigations. Smaller pieces were immersed in $2 \%$ glutaraldehyde buffered in $1 \mathrm{M}$ sodium phosphate ( $\mathrm{pH} 7.2$ ) for $24 \mathrm{~h}$ at $4^{\circ} \mathrm{C}$, washed in $1 \mathrm{M}$ sodium phosphate buffer and postfixed in $1 \%$ osmium tetroxide, buffered in $1 \mathrm{M}$ sodium phosphate for $1 \mathrm{~h}$ at room temperature. Tissue was dehydrated in ethanol and propylene oxide, infiltrated and embedded in Epon. Thin sections ( $80 \mathrm{~nm}$ thick) were stained with $5 \%$ uranyl acetate and lead. Sections were examined and photographed using a Hitachi Bio-TEM 7500 operated at $80 \mathrm{kV}$.

\section{RESULTS}

Xenomas of various stages of development were observed in gill tissue associated with the vasculature of filaments and lamellae. The identity of xenoma host cells could not be morphologically determined. Xenomas contained parasites in multiple stages of development (Fig. 1). The number of coils of the polar tube (17 to 19$)$ and size of mature spores $(4.0 \times 2.0 \mu \mathrm{m})$ were similar to those described for Loma morhua (Morrison \& Sprague 1981) (Fig. 2). A number of spores were empty and many had everted polar tubes.

Everted polar tubes, in transverse and longitudinal profiles, were seen scattered throughout the cytoplasm of the xenomas, and some of the polar tubes had pierced through the plasma membrane (Figs. $1 \& 2$ ). Polar tubes outside the xenoma were found in the extracellular matrix and beneath the basal lamina of the respiratory epithelium (Fig. 1). A few polar tubes appeared to have penetrated the basal lamina, and were seen external to the surface of the respiratory epithelium (Fig. 3). It was interesting to note that polar tubes were seen within the cytoplasm of erythrocytes adjacent to xenomas (Fig. 4). Polar tubes were also observed in the cytoplasm and nuclei of other cells that could not be morphologically identified, although a single mature spore surrounded by electron dense pansporoblastic matrix was seen in the cytoplasm of a leucocyte that appeared to be embedded in dense fibrillar material (Fig. 5).

\section{DISCUSSION}

Most microsporidia infections typically occur after ingestion of infective spores followed by invasion of epithelial cells and/or intraepithelial leucocytes (Didier 1998, Vivarès \& Méténier 2001). In fish infected with Loma sp., it has been suggested that early stages of the parasite (meronts) are transported via leucocytes to the gills, where they form xenomas (Rodriguez-Tovar et al. 2002). Xenomas rupture when the infected host cell or the host organism dies, and the spores gain access to the extracellular or external environment (Cali \& Takvorian 1999). Rupture of the xenoma might be followed by phagocytosis of the released spores, and could lead to the establishment of an intracellular infection (Bigliardi \& Sacchi 2001). Ramsay et al. (2001) reported xenomas in fish recovered from Loma sp. infections, and this suggests perpetuation of the disease by the awakening of a dormant infection previously held by the host immune system (Amigó et al. 1997).

The most important finding in this current work with cod was the observation of numerous intra- and extraxenomal everted tubes. Similar observations have been interpreted as evidence of autoinfection for Loma myrophis in the Amazonian fish Myrophis platyrhynchus (Matos et al. 2003). The possibility of microsporidian autoinfection in fish has been indicated by some authors as a very limited mechanism for transmitting infection (Lom \& Dyková 1992). Evidence in the present Loma sp. cod study, and previous observations for Loma sp. in rainbow trout (Rodriguez et al. 2002, 2003) and an Amazonian fish (Matos et al. 2003), suggest that autoinfection could be a common way for establishing a secondary infestation in the host by Loma sp., as was previously proposed in fish exposed to L. salmonae (Shaw et al. 1998).

Figs. 1 to 5. Loma sp. infecting Gadus morhua. Fig. 1. Margin of a xenoma containing mature spores (S), degenerated sporonts (*) and sections of everted polar tubes (arrowheads). An everted polar tube is seen piercing the xenoma plasma membrane. Everted polar tubes are also within the extracellular matrix (EM) and beneath the basal lamina (arrow) of a pavement cell (Ep). Scale bar $=0.9 \mu \mathrm{m}$. Fig. 2. Mature spores (S) within a xenoma show the characteristic number of coils associated with $L$. morhua. Note everted polar tubes (arrowheads) in the xenoma cytoplasm. Scale bar $=0.9 \mu \mathrm{m}$. Fig. 3 . Everted polar tubes (arrowheads) are seen within a xenoma (X), in the extracellular matrix (EM), penetrating the basal lamina (arrow) of pavement cells (Ep) and in the external environment $(*)$. Scale bar $=0.6 \mu \mathrm{m}$. Fig. 4. Polar tubes (arrowheads) in the cytoplasm of a red blood cell $(\mathrm{E})$. Scale bar $=$ $0.9 \mu \mathrm{m}$. Fig. 5. A leucocyte (L), embedded in fibrillar material (*), which contains a spore (S) covered by a pansporoblastic matrix (arrow). Scale bar $=1 \mu \mathrm{m}$ 


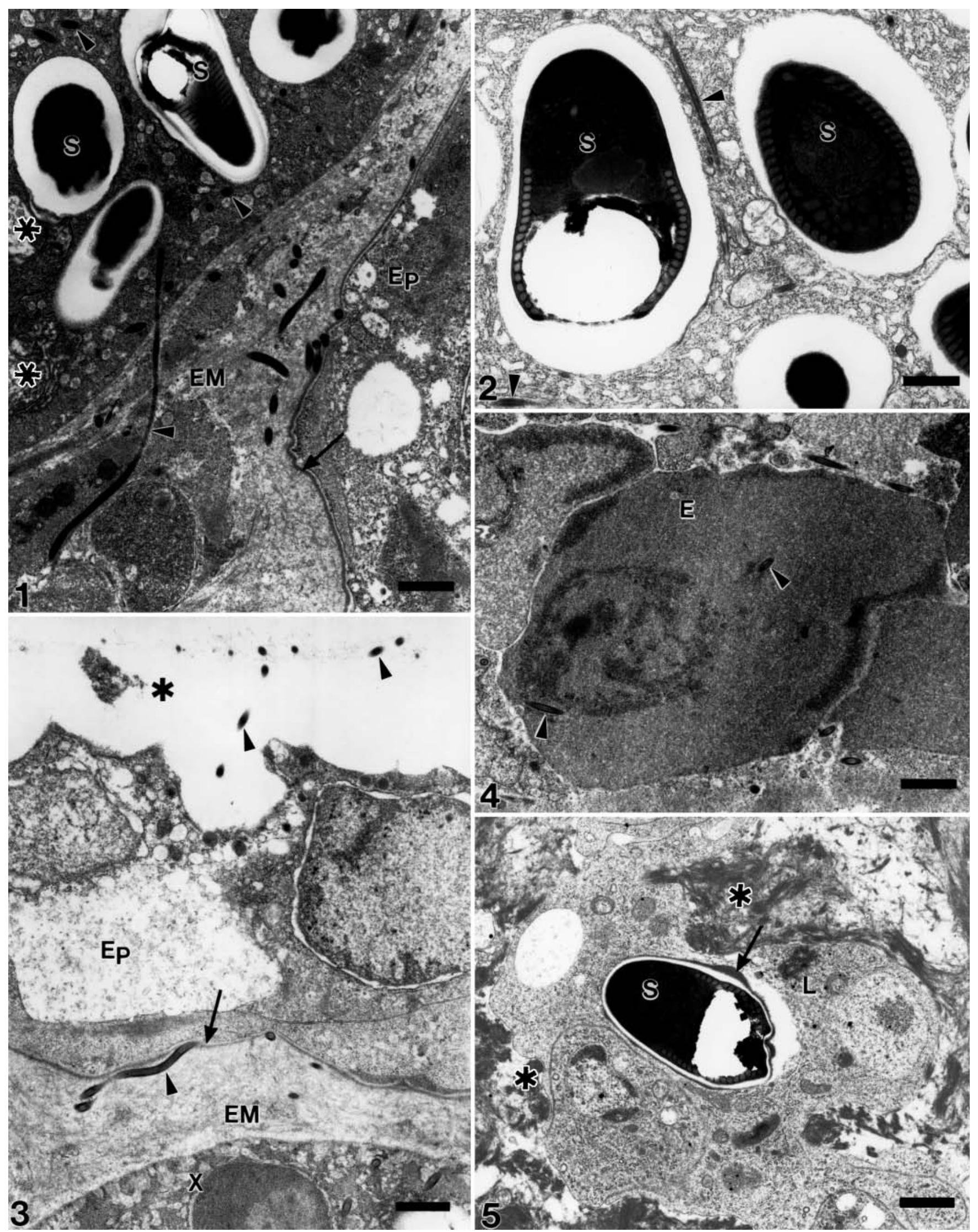


The reasons for eversion of the polar tubes are variable (Undeen 1990). It has been proposed that polartube eversion, and subsequent parasite entry into host cells, is induced by the parasite through specific interactions with receptors on phagocytes plasma membrane once both cells establish physical contact (Magaud et al. 1997). Some authors have hypothesized that speed and rigidity of the polar tube during extrusion it is not enough to penetrate a host cell membrane (Vivarès \& Méténier 2001). The present study, however, has shown that numerous everted polar tubes penetrate the xenoma plasma membrane, and that polar tubes are capable of piercing the cytoplasm and nuclei of many cell types, including red blood cells (RBCs) and leucocytes. Polar tubes were also observed outside of the gill lamella, in the external environment. This clearly indicates that, at least in Loma sp. infections, the spore germination mechanism drives enough force to penetrate not only one, but several cell types.

The role of leucocytes as vehicles for spreading microsporidian infections within the host has already been reported (Didier 1998, Cali \& Takvorian 1999, Couzinet et al. 2000). It was interesting to observe in this study that RBCs contained polar tubes in their cytoplasm, suggesting a parasite-transporting role for this cell. To date, there is no information in the literature regarding RBCs as possible transport vehicle. Some consider the presence of multiple parasites in different stages of development, and everted polar tubes within a xenoma, as evidence for autoinfection of itself (Cali \& Owen 1990, Matos et al. 2003). Reasons for re-infecting the same host cell are still unknown.

According to the present study, some mature spores within xenomas everted their polar tubes in all directions, with potential to start the parasite's proliferation both in the same xenoma and outside the xenoma in adjacent cells and tissues. Autoinfection could be considered as a way to perpetuate the disease in the susceptible host, and in a fish population over time. For instance, in cod infected with Loma sp., RBCs, leucocytes and other cell types could be candidates for spreading the disease within the host by autoinfection. In this way, fish already recovered from the disease would be reservoirs of infection and could lead to subsequent disease outbreaks. This would explain why some fish microsporidian infections establish themselves in a certain region, persisting in feral and cultured fish for a long time (Ramsay et al. 2001).

\section{LITERATURE CITED}

Amigó JM, Salvadó H, Gracia MP (1997) The pathologic cycle of the infection of the microsporidian Microgemma ovoidea (Thel., 1895) Amigo et al. 1996 in the liver of the
Red Band fish (Cepola macrophthalma L.). Parasitol Res 84:7-12

Bigliardi E, Sacchi L (2001) Cell biology and invasion of the microsporidia. Microbes Infect 3:373-379

Cali A, Owen RL (1990) Intracellular development of Enterocytozoon, a unique microsporidian found in the intestine of AIDS patients. J Protozool 37:145-155

Cali A, Takvorian PM (1999) Developmental morphology and life cycles of the microsporidia. In: Wittner M, Weiss LM (eds) The Microsporidia and microsporidiosis. ASM Press, Washington, DC, p 85-128

Couzinet S, Cejas E, Schittny J, Deplazes P, Weber R, Zimmerli S (2000) Phagocytic uptake of Encephalitozoon cuniculi by nonprofessional phagocytes. Infect Immunol 68: 6939-6945

Desportes-Livage I (2000) Biology of microsporidia. Contrib Microbiol 6:140-165

Didier ES (1998) Microsporidiosis. Clin Infect Dis 27:1-7

Lom J, Dyková I (1992) Microsporidia (Phylum Microspora Sprague, 1977). Protozoan parasites of fishes. Elsevier, Amsterdam, p 125-157

Lom J, Nilsen F (2003) Fish microsporidia: fine structural diversity and phylogeny. Int J Parasitol 33:107-127

Magaud A, Achbarou A, Desportes-Livage I (1997) Cell invasion by the microsporidium Encephalitozoon intestinalis. J Eukaryot Microbiol 44:81S

Matos E, Corral L, Azevedo (2003) Ultrastructural details of the xenoma of Loma myrophis (phylum Microsporidia) and extrusion of the polar tube during autoinfection. Dis Aquat Org 54:203-207

Morrison CM, Sprague V (1981) Electron microscopical study of a new genus and new species of microsporidia in the gills of Atlantic cod Gadus morhua L. J Fish Dis 4:15-32

Ramsay JM, Speare DJ, Sanchez JG, Daley J (2001) The transmission potential of Loma salmonae (Microspora) in the rainbow trout, Oncorhynchus mykiss (Walbaum), is dependent upon the method and timing of exposure. J Fish Dis 24:453-460

Rodriguez-Tovar LE, Wright GM, Wadowska DW, Speare DJ, Markham RJF (2002) Ultrastructural study of the early development and localization of Loma salmonae in the gills of experimentally infected rainbow trout. J Parasitol 88:244-253

Rodriguez-Tovar LE, Wright GM, Wadowska DW, Speare DJ, Markham RJF (2003) Ultrastructural study of the late development of Loma salmonae in the gills of experimentally infected rainbow trout. J Parasitol 89:464-474

Sánchez JG, Speare DJ, Markham RJF, Wright GM, Kibenge FSB (2001) Localization of the initial developmental stages of Loma salmonae in rainbow trout (Oncorhynchus mykiss). Vet Pathol 38:540-546

Shaw RW, Kent ML (1999) Fish Microsporidia. In: Wittner M, Weiss LM (eds) The Microsporidia and microsporidiosis. ASM Press, Washington, DC, p 418-446

Shaw RW, Kent ML, Adamson ML (1998) Modes of transmission of Loma salmonae (Microsporidia). Dis Aquat Org 33: 151-156

Speare DJ, Beaman HJ, Jones SRM, Markham RJF, Arsenault GJ (1998) Induced resistance in rainbow trout, Oncorhynchus mykiss (Walbaum), to gill diseases associated with the microsporidian gill parasite Loma salmonae. J Fish Dis 21:93-100

Undeen AH (1990) A proposed mechanism for the germination of microsporidian (Protozoa: Microspora) spores. J Theor Biol 142:223-235

Vivarès CP, Méténier G (2001) The microsporidian Encephalitozoon. Bioessays 23:194-202

Submitted: July 21, 2003; Accepted: August 28, 2003

Proofs received from author(s): December 1, 2003 